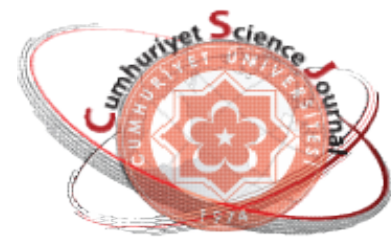

e-ISSN: $2587-246 X$

ISSN: 2587-2680

\section{Cumburiyet Science Journal}

CSJ

Cumhuriyet Sci. J., Vol.39-2(2018) 543-549

\title{
Comparison of Spectral Classification Methods in Water Quality
}

\author{
Önder GÜRSOY ${ }^{1^{*}}$, Rutkay ATUN ${ }^{1}$ \\ ${ }^{l}$ Cumhuriyet University, Dept. of Geomatics Engineering, Sivas, TURKEY
}

Received: 11.05.2018; Accepted: 31.05.2018

http://dx.doi.org/10.17776/csj.422897

\begin{abstract}
Today, water quality and water pollution can be detected using remote sensing and its terrestrial components. Remote sensing does not only provide a quick solution to detect water quality and pollution, but it could also be low cost. Within the scope of the study, the water quality of the İmranli area of the Kizılırmak River, one of the most important water resources of the Sivas region and the Imranlı dam on the river, was investigated by spectral classification methods. Water samples were taken from various points on the river and dam and their chemical oxygen demands were determined in the laboratory. In addition, the reflectance values of the water samples taken by the local spectral measurements were examined in order to use as end members for spectral classification. CHRIS Proba is used as satellite image. Match filtering (MF), spectral angle mapping (SAM) and spectral information divergence (SID) methods have been used as the spectral classification methods and it has been examined which method gives better results in determining water quality. According to the results, it is understood that SAM method provides better classification accuracy than other methods.
\end{abstract}

Keywords: CHRIS Proba, Hyperspectral remote sensing, Water quality, Spectral angle mapper, Match filtering, Spectral information divergence.

\section{Su Kalitesinin Sınıflandırılmasında Spektral Sınıflandırma Yöntemlerinin Karşılaştırılması}

\begin{abstract}
Özet:Günümüzde, uzaktan algılama ve yersel bileşenleri kullanılarak su kalitesi ve su kirliliğinin tespiti yapılabilmektedir. Uzaktan algılama, su kalitesini ve kirliğini tespit etmede hızlı bir çözüm sunmakla kalmaz aynı zamanda düşük maliyetli de olabilmektedir. Çalışma kapsamında Sivas bölgesinin en önemli su kaynaklarından biri olan Kızılırmak nehrinin İmranlı bölgesinin ve nehir üzerinde bulunan İmranlı barajının su kalitesi spektral sınıflandırma yöntemleri ile incelenmiştir. Nehir ve barajda çeşitli noktalardan su numuneleri alınıp bunların laboratuvarda kimyasal oksijen içerikleri tespit edilmiştir. Buna ek olarak alınan su numunelerinin yersel spektral ölçümlerle yansıtım değerlerine bakılmıştır. Ölçülen yansıtımlar uç üye olarak alınıp spektral sınıflandırmada referans olarak kullanılmıştır. Uydu görüntüsü olarak ise CHRIS Proba kullanılmıştır. Spektral sınıflandırma yöntemleri olarak ise eşleşen filtreleme (MF), spektral açı haritalama (SAM) ve spektral bilgi ayrımı (SID) yöntemleri kullanılmış olup hangi yöntemin su kalitesi tespitinde daha iyi sonuç verdiği irdelenmiştir. Sonuçlara göre SAM yönteminin diğer yöntemlere göre daha iyi sınıflandırma doğruluğu sağladığg anlaşılmıştır.
\end{abstract}

AnahtarKelimeler: CHRIS Proba, Aşırı spektral uzaktan algılama, Su kalitesi, Spektral açı haritalama, Eşleşen filtreleme, Spektral bilgi ayrımı

\section{INTRODUCTION}

Remote sensing is frequently used in environmental analysis and monitoring studies such as agriculture, mining, geology, ecosystem, urbanization, forestry today [1]. Thanks to remote sensing and its terrestrial components, many scientific studies can be

\footnotetext{
* Corresponding author. Email address: ogursoy@cumhuriyet.edu.tr http://dergipark.gov.tr/csj C2016 Faculty of Science, Cumhuriyet University
} 
done quickly, effectively and at low cost. One of the uses of remote sensing related to the environment and ecosystem is the detection and monitoring of water quality.

Although water and water management is a crucial factor for sustainable development, accessing to clean water is becoming difficult. Urbanization, industrialization, increasing agricultural and animal activities and better governance of water resources along with the global warming process have become more important.

In this study, the effect of other water resources in the region was also investigated. In the study conducted at the Derbent dam located on the Kizılırmak River, water samples were taken from various points and tested in the laboratory environment. The water samples were examined for their heavy metal content. Criteria such as $\mathrm{pH}$, degree, amount of dissolved oxygen and electrical conductivity have also been evaluated. It has been determined that $\mathrm{Zn}$ and $\mathrm{Pb}$ values are above the limits according to the work done [2].

In the study performed by Taş (2006), conducted at the Derbent dam, water samples were taken from various points on the dam surface and these were examined in the laboratory environment. Factors such as temperature, $\mathrm{pH}$, dissolved oxygen, conductivity, alkalinity, cation sequencing and anion sequencing were investigated. When the physical and chemical analysis data are evaluated, it is found that the dam is a suitable environment for aquaculture [3].

Water pollution also could be investigated remote sensing technology. In remote sensing, there are many studies related to water and water pollution. There are also many studies that uses hyperspectral images, in situ measurements, thermal images or geographic information systems were used to determine water quality in remote sensing $[4,5,6,7]$. The criteria examined in these studies can be described as turbidity, amount of suspended matter, content of chlorophyll, temperature, amount of organic and inorganic substances [819].

In situ measurements were performed with aqua meter water quality instrument in a study performed by Rostam et al (2017). Temperature, $\mathrm{pH}$, turbidity, chlorophyll and dissolved oxygen values were measured by Aqua meter. Water samples were also taken from these points and the heavy metal content was examined in the laboratory. In addition, the spectral reflectance of the water samples through the ASD Field Spec Pro 3 have been examined. It has been investigated in which region of the electromagnetic spectrum the reflectance changes depending on the pollution. Finally, laboratory studies and empirical values were integrated using a statistical regression model and water pollution was identified [20].

ASTER satellite image was used to determine water quality in another study conducted by Abdelmalik (2016). The precise estimation of missing data in a given area in order to develop a mathematical relationship is the main purpose of this work. The water quality parameters obtained from ASTER data include temperature, turbidity, hydrogen ion concentration, salinity, electrical conductivity, total alkalinity, total organic carbon and orthophosphorus. While the relationship between ASTER values and water quality parameters for mathematical model construction was given, other sample data were used to test the obtained model. As a result of the regression analysis made between the constructed model and remote sensing data, places with water pollution were determined [21].

In this study, water pollution was investigated by using spectral signatures obtained with spectroradiometer measurements and hyperspectral image. As a satellite remote sensing data, Chris Proba hyperspectral satellite image was preferred to use. In this context, Turkey's longest river Kizilırmak River's İmranlı region was selected as study area and water samples were taken from various places on the river. Spectroradiometer measurements of water samples were made and the resulting 
reflectance were used as an end member in the spectral classification Chris Proba hyperspectral satellite image. Match Filtering (MF), Spectral Angle Mapper (SAM) and Spectral Information Divergence (SID) were used as spectral classification methods. It has been researched which classification method works best. Match Filtering (MF), Spectral Angle Mapper (SAM) and Spectral Information Divergence (SID) spectral classification methods were compared to determine the best. In order to test the accuracy of the spectral classifications, a laboratory analysis of the points where the water samples were taken and the COD (Chemical Oxygen Demand) values were examined.

\section{STUDY AREA}

Imranl1 region of Kizllirmak River that is the longest river in Turkey with $1355 \mathrm{~km}$ length and İmranlı dam were selected as study area.(figure 1). Kizilirmak is one of the most important water resources of the region and it is frequently used in agricultural irrigation the most important water source that fed to İmranlı dam is Kizılırmak River.

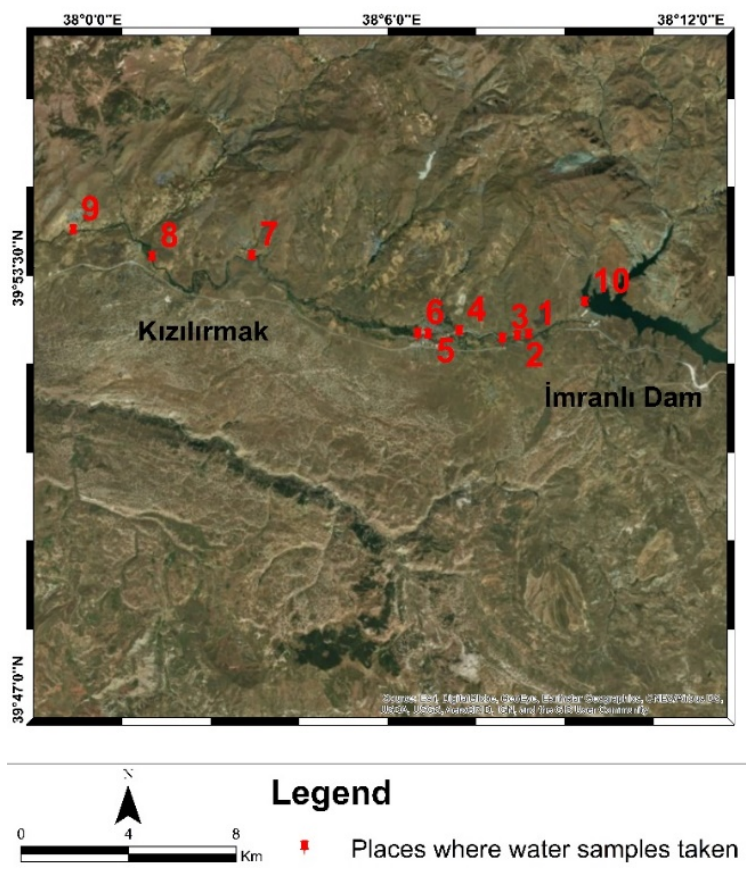

Figure 1. Study Area

\section{MATERIAL AND METHOD}

Chris PROBA satellite image (CHRIS_IM_140830_OC61_41 - acquisition date: 25 March.2015) provided free of charge by the European Space Agency for the study. The Chris PROBA sensor provides high spatial resolution in the near infrared and visible regions of the electromagnetic spectrum. Chris PROBA provides a total spatial resolution of 18 meters in a $15 * 15 \mathrm{~km}$ area on a total of 18 band (in mode 3 ) [22, 23, 24]. In order to make the terrestrial spectral measurements, ASD Field Spec Pro 4 device capable of recording between 350 and 2500 nanometers was used.

Within the scope of the study, water samples were taken from various points in the river and dam. The reflectance values of the water samples were measured by spectroradiometer. These reflectance values were then re-sampled to the Chris PROBA satellite image band intervals in order to use in spectral classification. In addition, the water samples were taken to the laboratory and chemical oxygen demand (COD) was investigated. Water quality analysis, which is evaluated according to COD values, was carried out (table 1) based on the Water Pollution Control Regulation of the Ministry of Environment and Urbanization [24].

Table 1. Chemical Oxygen Demand Measurement [26]

\begin{tabular}{cc}
\hline Locations & $\begin{array}{c}\text { Chemical Oxygen } \\
\text { Demand }\end{array}$ \\
\hline 1 & 10 \\
3 & 17 \\
4 & 8 \\
5 & 32 \\
6 & 8 \\
7 & 6 \\
8 & 35 \\
9 & 4 \\
10 & 19 \\
\hline
\end{tabular}

Radiometric and atmospheric corrections of the Chris PROBA image was made via Beam Visat software which was developed by BrockmannConsult with ESA support [27]. The geometric correction of the image was made according to 
37th zone of the UTM projection system. Reflectance values obtained from the spectroradiometer were used as end members for the spectral classification. MF, SAM and SID were used as spectral classification methods.

The MF maximizes the response of the reference end members and is a method of suppressing the knowledge of irrelevant reflections. [28].

The SAM is known to use an n-dimensional angle to match the pixels with the reference spectra, with a physically-based spectral classification. SAM is a classification method that allows fast mapping and calculates the spectral similarity between the reference reflection spectra between image spectra [29, 30].

The SID is a classification method that reduces each pixel spectrum as a random variable when measuring the inconsistency of the probabilistic behavior between two spectra [31].

\section{DISCUSSIONS of RESULTS and CONCLUSIONS}

In this study, the accuracy of spectral classification methods was tested to determine water quality through Chris PROBA satellite and terrestrial spectral measurement technique. MF, SID and SAM were used as

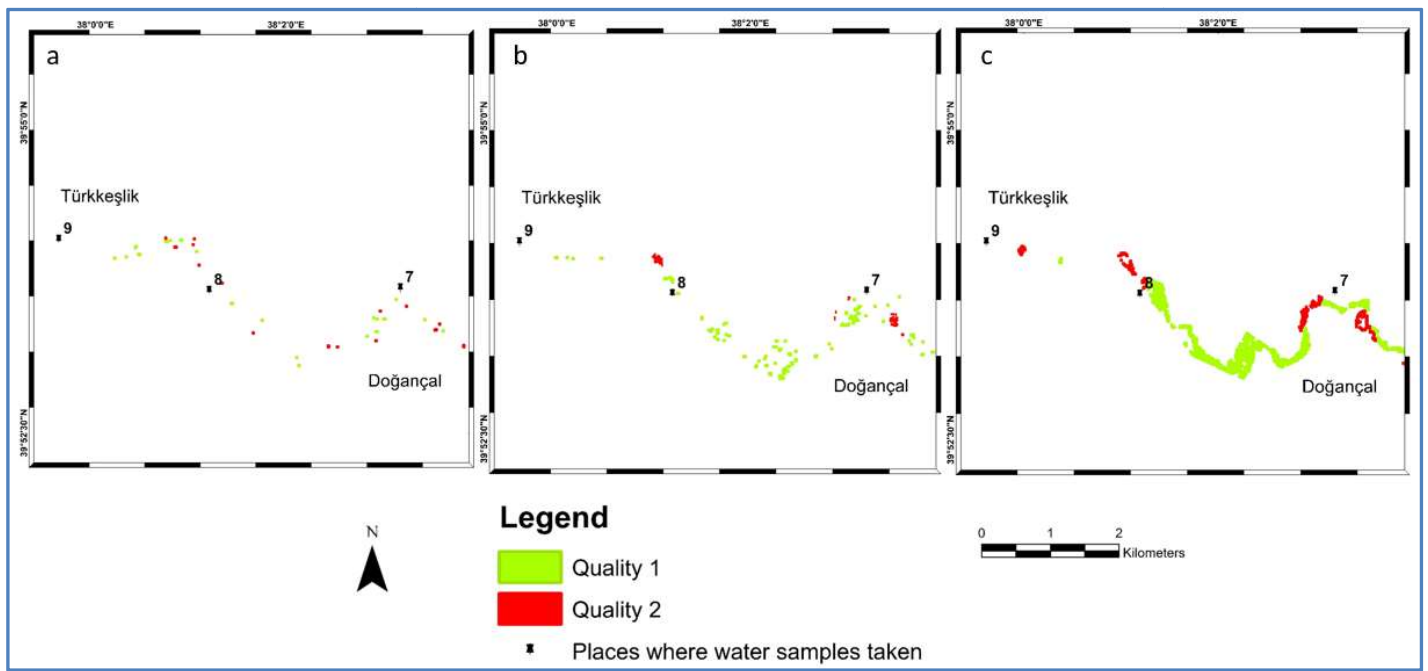

Figure 2. Result of spectral classifications. a) Result of MF b) Result of SID c) Result of SAM.

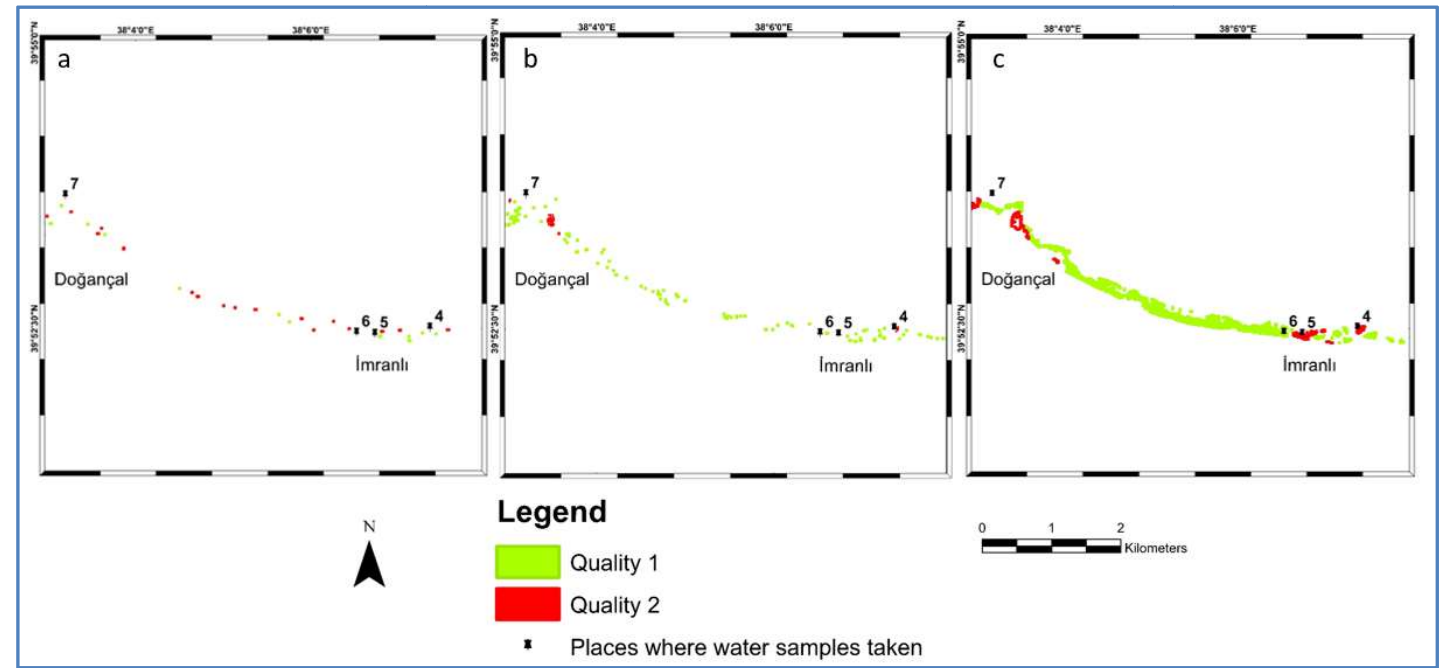

Figure 3. Result of spectral classifications. a) Result of MF b) Result of SID c) Result of SAM. 


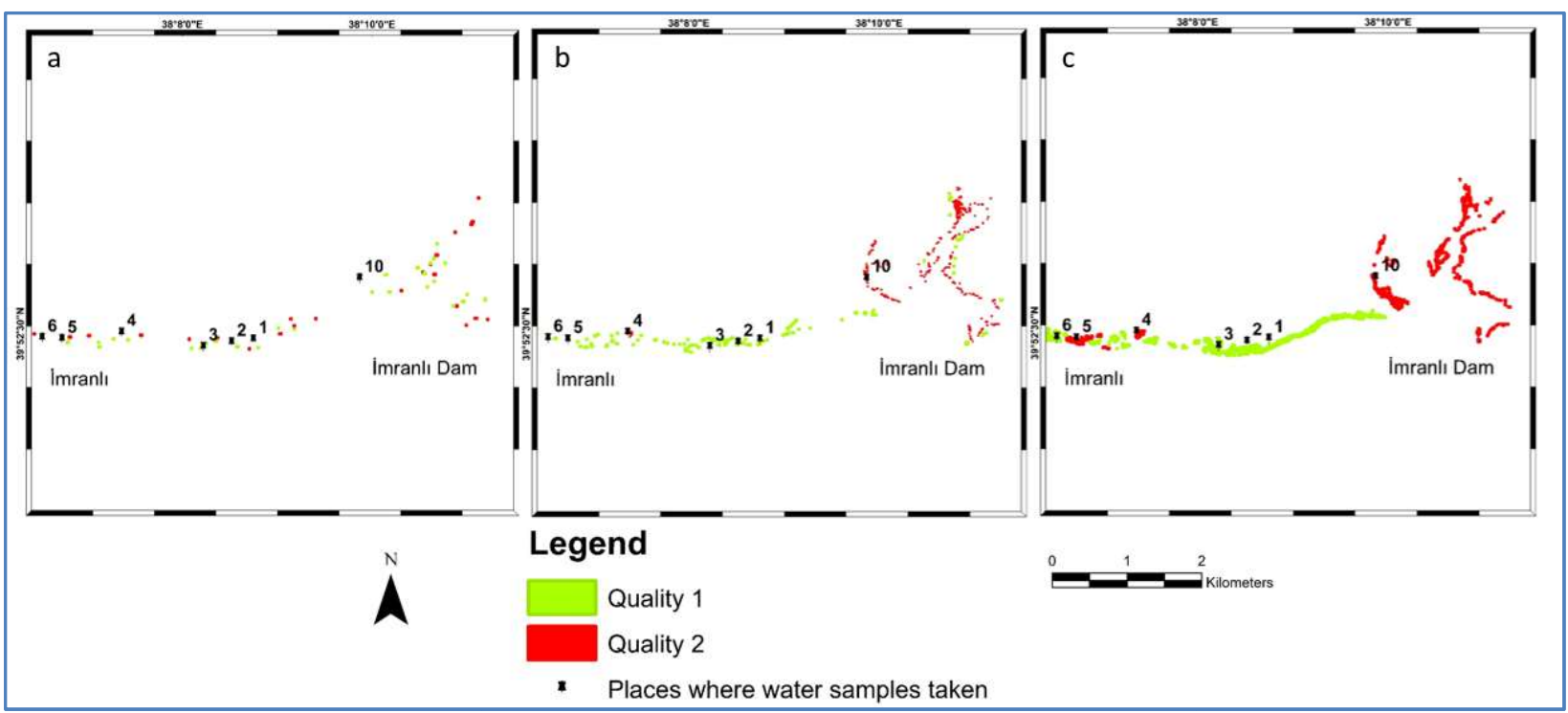

Figure 4. Result of spectral classifications. a) Result of MF b) Result of SID c) Result of SAM.

In the laboratory, first quality water was emerged at points $1,2,3,4,6,7,9$ and 10 according to COD analysis. It was also revealed that the water samples taken from points at 5 and 8 were second quality.

According to the applied spectral classification methods, the best results are SAM, SID and MF with the accuracy assessment of classification methods are $80 \%, 75 \%, \% 65 \%$ respectively. The spatial resolution of Chris PROBA adaptation is 17 meters, which significantly affects the classification accuracy. If an image with a higher spatial resolution is used, the classification accuracy will also increase.

According to the results, it is understood that the quality of the water in the İmranlı region of the Kizılırmak river is generally first quality. It is revealed that water quality of İmranlı dam is generally second quality. The reason is that the Imranlı dam is fed from other water sources and water in the dam is in a stagnant state. It is thought that agricultural activities and wastes also affect water quality.

\section{Acknowledgements}

We want to thank CUBAP (Cumhuriyet University Scientific Research Projects) for M 614 numbered Project's data and their cooperation.

\section{REFERENCES}

[1]. Karaman M.,Budakoğlu M., Uca Avc1 Z.D., Özelkan E., Bülbül A., Civas M., Tasdelen S., Determination of Seasonal Changes İn Wetlands Using Chris/PROBA Hyperspectral Satellite Images: A Case Study From Acıgöl (Denizli), Turkey, Journal of Environmental Biology., 36 (2015) 73 83.

[2]. Akbulut A. and Akbulut N., The Study of Heavy Metal Pollution and Accumulation in Water, Sediment, and Fish Tissue in Kizilirmak River Basin in Turkey, Environmental Monitoring and Assessment., 167 (2010) 521-526.

[3]. Taş B., Investigation of Water Quality of Derbent Dam Lake (Samsun) Ekoloji., 60 (2006) 6-15.

[4]. Giardino C., Candiani G., Bresciani M., Lee Z., Gagliano S., Pepe M., BOMBER: A Tool for Estimating Water Quality and Bottom Properties from Remote Sensing Images, Computers and Geosciences., 45 (2012) 313-318.

[5]. Olmanson L.G., Brezonik P.L., Bauer M.E., Airborne Hyperspectral Remote Sensing to Assess Spatial Distribution of Water Quality Characteristics in Large 
Rivers: The Mississippi River and its Tributaries in Minnesota, Remote Sensing of Environment. 130 (2013) 254265.

[6]. Kaya Ş., Başar U.G., Karaca M., Şeker D.Z., Assessment of Urban Heat Islands Using Remotely Sensed Data, Ekoloji., 21 (2012) 107-113.

[7]. Torgersen C.E., Faux R.N., Mcintosh B.A., Poage N.J., Norton D.J., Airborne Thermal Remote Sensing for Water Temperature Assessment in Rivers and Streams, Remote Sensing of Environment., 76 (2001) 386-398.

[8]. Mattikalli N.M., Richards K.S., Estimation of Surface Water Quality Changes in Response to Land Use Change: Application of the Export Coefficient Model Using Remote Sensing and Geographical Information System, Journal of Environmental Management., 48 (1996) 263-282.

[9]. Giardino C., Candiani G., Bresciani M., Lee Z., Gagliano S., Pepe M. BOMBER: A tool for estimating water quality and bottom properties from remote sensing images. Computers and Geosciences 2012; 45: 313-318.

[10]. Urbanski A., Wochna J., Bubak A., Grzybowski I., Matuszewska W.L., Lącka K., Śliwińska M., Wojtasiewicz B., ZajączkowskI B., Application of Landsat 8 Imagery to Regional-Scale Assessment of Lake Water Quality, International Journal of Applied Earth Observation and Geoinformation., 51 (2016) 28-36.

[11]. Dlamini S., Nhapi I., Gumindoga W., Nhiwatiwa T., Dube T., Assessing the Feasibility of Integrating Remote Sensing and In-Situ Measurements in Monitoring Water Quality Status of Lake Chivero, Zimbabwe, Physics and Chemistry of the Earth., 93 (2016) 2-11.

[12]. Chawira M., Dube T., Gumindoga W., Remote Sensing Based Water Quality Monitoring in Chivero and Manyame
Lakes of Zimbabwe, Physics and Chemistry of the Earth., 66 (2013) 38-44.

[13]. Umar M., Rhoads B.L., Greenberg J.A., Use of Multispectral Satellite Remote Sensing to Assess Mixing of Suspended Sediment Downstream of Large River Confluences, Journal of Hydrology., 556 (2018) 325-338.

[14]. Kaya Ş., Şeker D.Z., Tanik A., Temporal Impact of Urbanization on the Protection Zones of Two Drinking Water Reservoirs in Istanbul, Fresenius Environmental Bulletin., 23 (2014) 2984-2989.

[15]. Marquez L.C.G., Bejarano F.M.T., Espinoza A.C.T., Rodríguez I.R.H., Use of LANDSAT 8 Images for Depth and Water Quality Assessment of El Guájaro Reservoir, Colombia, Journal of South American Earth Sciences., 82 (2018) 231-238.

[16]. Masocha M., Murwira A., Magadza C.H.D., Hirji R., Dube T., Remote Sensing of Surface Water Quality in Relation to Catchment Condition in Zimbabwe, Physics and Chemistry of the Earth., 100 (2017) 13-18.

[17]. Olmanson L.G., Brezonik P.L., Finlay J.C., Bauer M.E., Comparison of Landsat 8 and Landsat 7 for Regional Measurements of CDOM and Water Clarity in Lakes, Remote Sensing of Environment., 185 (2016) 119-128.

[18]. Kiefer I., Odermatt D., Anneville O., Wüest A., Bouffard D., Application of Remote Sensing for the Optimization of In-Situ Sampling for Monitoring of Phytoplankton Abundance in a Large Lake, Science of the Total Environment., 527 (2015) 493-506.

[19]. Dörnhöfer K. and Oppelt N., Remote Sensing for Lake Research and Monitoring - Recent advances, Ecological Indicators., 64 (2016) 105122.

[20]. Lotfinasabasl S., Gunale V.R., Khosroshahi M., Applying Geographic Information Systems and Remote Sensing for Water Quality Assessment of 
Mangrove Forest, Acta Ecologica Sinica., 38 (2018) 135-143.

[21]. Rostom N.G., Shalaby A.A., Issa Y.M., Afifi A.A., Evaluation of Mariut Lake Water Quality Using Hyperspectral Remote Sensing and Laboratory Works, The Egyptian Journal of Remote Sensing and Space Science., 20 (2017) 39-48.

[22]. Abdelmalik, K. W., Role of Statistical Remote Sensing for Inland Water Quality Parameters Prediction, Egyptian Journal of Remote Sensing and Space Science., (2016); doi 10.1016/j.ejrs.2016.12.002: 1-8.

[23]. Rautiainen M., Lang M., Mõttus M., Kuusk A., Nilson T., Kuusk J., Lükk T. Multi-angular reflectance properties of a hemiboreal forest: An analysis using CHRIS PROBA data. Remote Sensing of Environment 2008; 112: 2627-2642.

[24]. Chan Wai J.C., Beckers P., Spanhove T., Vanden Borre J., An Evaluation of Ensemble Classifiers for Mapping Natura 2000 Heathland in Belgium Using Spaceborne Angular Hyperspectral (CHRIS/Proba) Imagery, International Journal of Applied Earth Observation and Geoinformation., 18 (2012) 13-22.

[25]. Demarchi L., Chan J.C.W., Ma J., Canters F., Mapping Impervious Surfaces from Superresolution Enhanced CHRIS/Proba Imagery Using Multiple Endmember Unmixing, ISPRS Journal of Photogrammetry and Remote Sensing., 72 (2012) 99-112.

[26]. Republic of Turkey, Ministry of Environment and Urbanization, Laws on Management of Water Pollution www.csb.gov.tr/db/cygm/editordosya/Y ON-25687SKKY.docx URL (accessed on 15.02.2014).

[27]. Gürsoy Ö., Birdal A.C., Özyonar F., Kasaka E., Determining And Monitoring The Water Quality Of Kizilirmak River Of Turkey: First Results, The International Archives of the Photogrammetry, Remote Sensing and Spatial Information Sciences, Volume
XL-7/W3， 2015 36th International Symposium on Remote Sensing of Environment, 11-15 May 2015, Berlin, Germany.[27] Millán V.E.G., SanchezAzofeifa G.A., Malvárez G.C., Mapping Tropical Dry Forest Succession with CHRIS/PROBA Hyperspectral Images Using Nonparametric Decision Trees, IEEE Journal of Selected Topics in Applied Earth Observations and Remote Sensing., 8 (2015) 3081-3094.

[28]. Gürsoy Ö., Canbaz O., Gökçe A., Atun R., Spectral Classification in Lithological Mapping; A Case Study of Matched Filtering, Cumhuriyet Science Journal., 38 (2017) 731-737.

[29]. Park B., Windham W.R., Lawrence K.C., Smith D.P., Contaminant Classification of Poultry Hyperspectral Imagery Using a Spectral Angle Mapper Algorithm, Biosystems Engineering., 96 (2017) 323333.

[30]. Girouard G. and Bannari A., Validated Spectral Angle Mapper Algorithm for Geological Mapping: Comparative Study Between QuickBird and Landsat-TM. XXth ISPRS Congress Istanbul, 2004: 599-604.

[31]. Chang C., Spectral Information Divergence for Hyperspectral Image Analysis, IEEE International Geoscience and Remote Sensing Symposium Hamburg, 1999: 509-511. 